\title{
The EU Concept of The Rule of LAW and The Procedures de lege lata AND de lege ferenda for its Protection
}

\author{
Naděžda Šišková \\ Jean Monnet Centre of Excellence in EU Law, Faculty \\ of Law, Palacky University, Czech Republic \\ nadezda.siskova@upol.cz
}

ŠIŠKOVÁ, Naděžda. The EU Concept of the Rule of Law and the Procedures de lege lata and de lege ferenda for its Protection. International and Comparative Law Review, 2019, vol. 19, no. 2, pp. 116-130. DOI: 10.2478/iclr-2019-0017.

\begin{abstract}
Summary: The article is dealing with the EU current and future intruments for the protection of the rule of law principles at the level of the European Union. The beginning is dedicated to the EU concept of the rule of law as an integral part of the Common European values and its significant for the smooth functioning of the area of freedom, security and justice. The substantial part of the study is focusing of the analysis of different procedures (infringement, political and administrative), which can be used for the protection of the rule of law principles, including highlighting their certain peculiarities and the limits. The end of the article contains the conclusions about future prospects.
\end{abstract}

Keywords: Common European values, rule of law principles, infringement procedure (art. 258 TFEU), political procedure (art. 7 TEU), new framework for strengthen the rule of law, European Court of the EU

\section{Introductory remarks}

The European Union's concept of the rule of law occupies a central and a key position among the common European values (Art. 2 TEU), not only due to the fact, that it creates a "backbone of any modern constitutional democracy“" ${ }^{\text {, but }}$ also as a conditio sine qua non for the entire functioning of the European Union as an area of freedom, security and justice (EAFSJ). This utterance is confirmed by the fact, that a lot of legal institutes of EAFSJ are based on the mutual confidence in the democratic character of the construction and functioning of the political and legal systems of each of these countries. Otherwise, the realisation of these institutes is jeopardised, as it can be illustratied, for instance, at the example of the European arrest warrent, which supposes the recognition and enforcement of the judgements of the other Member States. The same refers to the judgements

1 Communication from the Commission to the European Parliament and the Council „A new EU Framework to Strengthen the Rule of Law“, Strabourg, 11. 3. 2014, COM (2014) 158 final, p. 2 
in civil and commecial matters, which must also be automatically recognised in other Members States without reexamination. So it seems quiet logical the conclusion, that without the proper functioning of the democratic institutions and the observance of other principles of the rule of law, the area of freedom, security and justice cannot exist at all and thus this whole legal concept will be crashed. ${ }^{2}$

\section{European Union's concept of the rule of law - „old“ principles in a „new coat"?}

As it was already mentioned, the rule of law creates an integral part of the common European values, which are enumerated in Article 2 TEU, which states: „The Union is founded on the values of respect of human dignity, freedom, democracy, equality, rule of law and respect for human rights, including the rights of persons belonging to minorities. These values are common to the Member States in a society in which pluralism, non-discrimination, tolerance, justice, solidarity and equality between women and men prevail.“

This provision goes far beyond and significantly crosses over the dimension of the purely legal norm, as it also creates an ideological and moral basis, on which the European Union is founded. In this respect it can be shared the opinion, that „values have an ethical-political dimension that exceed the legal sphere". ${ }^{3}$

Analysis of this norm in the connection with the text of Article 3 TEU enables to detect the distinct shift after the Lisbon Treaty in the EU priorities from the economic aspects to the accentuation of its values. As Stephen Weatherall pertinently notes: „The prominence of the economic ambitions of the project has gone missing, and this sense of adjusted priority is accentuated by Article 3 TEU. It too insists on the force of values in guiding the Union's trajectory. According to Article 3 (1) TEU, the Union's aim ,is to promote peace, its values and well -beings of its people“. Only lower down the list, tucked away without fanfare in Article 3 (3), does the instruction to the Union „to establish an integral market emerge..." Article 3 (5) turns the EU's face outwards, and insists that in its relations with the wider world "the Union shall uphold and promote its values and interests and contribute to the protection of its citizens" and shall contribute to (inter alia) peace, security, free and fair trade, and the protection of human rights. ${ }^{\text {"4 }}$

2 ŠIŠKOVÁ, Naděžda. European Union's Legal Instruments to Strengthen the Rule of Law, their Actual Reflections and Future Prospects in: Šišková, N. (ed.): The European Union What is Next? A legal Analysis and the Political Visions on the Future of the Union, Wolters Kluwer Deutschland, Koln, 2018, p. 140

3 SCHROEDER, Werner: The EU Founding values - Constitutional Character and Legal Implications in: European Studies. The Review of European Law, Economics and Politics, 2016, vol. 3, p. 57.

4 WEATHERILL, Stephen: Law and Values in the European Union, Oxford University Press, Oxford, 2016, p. 394 
The rule of law, as a key element of these common European values finds its expression at the EU level in the sever dimesions, as it is pointed out aptly in jurisprudence:

1. The trans-national dimension between the Member States;

2. The integral dimension of the European Union;

3. The domestic dimension of every Member State ${ }^{5}$;

4. The external dimension the European Union ${ }^{6}$

Although the fact, that the third mentioned dimension, the rule of law at the domestic level of each Member State, at first glance it seems not to belong to the EU level, nevertheless in fact, as it will be shown latter, it plays an irreplaceable role in the maintance of the principles of the rule of law in the whole of the European Union's area. That is why the EU instruments for the protection of the rule of law can be used against the concerned Member State even in those cases, when the breach of the rule of law principles from its side has a purely national dimension (see below).

Concerning the notion of the rule of law, its content and structural elements, it is necessary to point out, that the primary law doesn't bring an exhaustive and comprehensive answer. So it must be found in other sources of EU law, including the Charter of Fundamental Rights of the $\mathrm{EU}^{7}$, secondary legislation, constant case-law of the CJEU and the acts of sui generis.

From the beginning, it is worth focusing on the case-law of the Court of Justice of the EU, which is traditionally dealing with the different aspects of the rule of law concept.

The Luxembourg Court was the first, that had formulated the main principles and other structural elements of the rule of law, which are fully applicable within the European Community/Unions' legal system. They are for instance: the protection of fundamental rights, prohibition of discrimination, principle of legality, legal certainty, prohibition of artitrainess of executive powers, equality before the law, different rights of a procedural character - (the right to fair trial) an independent and effective judicial review, etc ${ }^{8}$. The Court of Justice of

5 MULLER-GRAFF, Peter-Christian. The Idea and Rule of Law as Foundation of the EU Acquis in Šišková Naděžda (ed.) From Eastern Partnership to the Association: A Legal and Political Analysis, Cambridge Scholar Publishing, June 1, 2014

6 ŠIŠKOVÁ, Naděžda, ibid, p. 138

7 For the mechanism of the enforcement of the Charter see HAMULAK, Ondrej: The Variations of Judicial Enforcement of the EU Charter of Fundamental Rights vis-á-vis Union Institutions and Bodies in: European Studies. The Review of European Law, Economics and Politics, 2018, vol. 5, p. 98-112, see also DAMINOVA, Nasiya: The Charter of Fundamental Rights of the European Union as a factor affecting the „European consensus" notion (the example of due process rights) in: European Studies. The Review of European Law, Economics and Politics, 2017, vol. 4, p. 28-55

8 For detailed overview of these princples see ŠIŠKOVÁ, Naděžda, Dimenze ochrany lidských 
the European Union formulates and declares these principles, determinates the conditions of their application (including their certain possible limits), as well as their relationship to other sources of European law. These principles later on were reflected in the secondary legislation and in the Charter of Fundamental Rights of the EU. The Court of Justice has also repeatedly pointed out in its judgements on the significance of the rule of law for the smooth functioning of the supranational entity.

Especially, in the Les Verts case, it stated that „Community based on the rule of law, inasmuch as neither its Member States, nor its institutuions can avoid a review of the question of whether the measures adopted by them are in conformity with the basic constitutional charter, the Treaty".

This already legendary statement of the Court, which was declared almost 40 years ago, was complemented by its recent ratione decidendi in the Opinion 2/13, by which: „the system is based on the fundamental premiss that each Member State shares with all the other Member States, and recognises that they share with it, a set of common values on which the EU is founded, as stated in Article 2 TEU. That premiss implies and justifies the existence of mutual trust between the Member States that those values will be recognised and, therefore, that the law of the EU that implements them will be respected"10

The Court, while formulating the principles of the rule of law applicable for the EU as a supranational entity, is looking for its inspiration in the different sources adopted at the national and international level.

For instance, the Luxembourg Court always analyses and gathers from the constitutional principles and traditions, which are inherent to the Member States. This enables (inter alia) to conclude, that the rule of law is a common denominator in modern European constitutional traditions.

As the sources of the Court's inspiration it can be mentioned also the international documents of a universal character (for instance, the United Nations Universal Declaration on Human Rights), as well as different Internation acts adopted at the regional level. In this respect it must be pointed out primarely on the decisive influence of the intellectual background of the Council of Europe, which is not limited only to the Convention on the Protection of Human Rights and Fundamental Freedom, but covers also other legal instruments adopted in the framework of the Strasbourg system, as well as it refers to the relevant caselaw of the European Court of Human Rights while creating the EU concept of the rule of law.

The judgements of the Luxembourg Court, as well as other sources of EU law (especially, the secondary legislation) are usually gathering also from the differ-

práv v Evropské unii, 2 edition, Linde, Prague, 2008, p. 91-92

9 C-294/83, Les Verts vs. Parliament, ECLI:EU:EC:1986:166, para. 23

10 Opinion 2/13 of the Court, 18 December 2014, ECLI:EU:C:2014:2454 
ent analytic documents elaborated in the framework of the Council of Europe in this field, for instance the reports of the Venice Commission (European Commission for Democracy through Law). The decisive role of the mentioned comparative studies on the creation of the EU concept of the rule of law can be clearly illustrated on the example of the Communication of the European Commission to the European Parliament and the Council from 12. 3. 2014 „A new Framework to strengthen the Rule of Law “. ${ }^{11}$ In this act of the secondary law the European Commission takes over the entire definition, content and the structural elements of the rule of law, as are described in the Report on the Rule of Law adopted by the Venice Commission in $2011^{12}$.

So, it can be summarised, that the European Commission makes a verbation reception of the definition and the core elements of the rule of law and shares the main conclusions in this field with the intellectual background of the Council of Europe.

The Venice Commission defines the rule of law as „a fundamental and common European standard to guide and constrain the exercise of democratic power" ${ }^{13}$ and also as „an inherent part of any democratic society“. It explaines, that "the notion of the rule of law requires everyone to be treated by all decisionmakers with dignity, equality and rationality and in accordance with the law, and to have the opportunity to challenge decisions before independent and impartial courts for their unlawfulness, where they are accorded fair procedures". ${ }^{14}$

Under the Report on the Rule of Law to this notion belongs the necessary elements, which are not only formal but also substantional (material). They are:

1. „Legality, including a transparent, accountable and democratic process for enacting law;

2. Legal certainty;

3. Prohibition of arbitrariness;

4. Access to justice before independent and impartial courts, including judicial review of administrative acts;

5. Respect for human rights;

6. Non-discrimination and equality before law." ${ }^{15}$

It is very important to underline, that it is not a complete and not an exhaustive list of all the integral parts of the rule of law, but only those of it, where

11 Communication from the Commission to the European Parliament and the Council „A New Framework to Strengthen the Rule of Law“, COM (2014) 158 final, Strasbourg: 12. 3. 2014

12 Report on the Rule of Law adopted by the Venice Commission at its 86th plenary session (Venice, 25-26 March 2011, study no 512/2011, Strabourg 4 April 2011, CDL-AD (2011), $003 \mathrm{rev}$

13 Ibidem, p.14

14 Ibidem, p. 5

15 Ibidem, p. 10 
„a consensus can be found on the necessary elements of the rule of law". ${ }^{16}$ Of course it deserves the enumeration of other elements, which are enherent for democratic society.

This non-exhausive list of the core elements of the rule of law is supplemented in the Report by the brief explanation of each of these structural parts of the rule of law.

The Venice Commission in its comparative study also pointed out the fact, that ,the legal provisions referring to the rule of law, both at national and international level, are of a very general character and do not define the concept in much detail. ${ }^{\text {"17 }}$ This opinion can be unambiguously shared, especially if we will look at the text of the already mentioned Article 2 TEU. This provision, which creates a declaration with an enormous political and moral authority, nevertheless in legal terms does not bring any definition of the rule of law or of its content. Besides, some of the common values, which are also enumerated in this article as the separate notions, in fact create an integral parts and structural elements of the meaning of rule of law itself (for instance respect for human rights, equality, non-discrimination, etc.). This confusion in terms surely deserves a proper explanation. It can hardly be supposed, that the authors of this article do not know the precise content of the rule of law notion. Obviously, the double mentioning was done for the purposes of the greater accentuation of the relevant principles. In all the cases, the text of Art. 2 TEU undoubtely demands the adoption of other norms, which will explain and precise this declaration. As such an explanation can be considered the already mentioned Communication „A new Framework to strengthen the Rule of Law", which was adopted by the Commission just for the protection of these principles.

So, it can be concluded, that the EU concept of the rule of law is based on the traditional approaches, which are inspired by and gathered from the Constitutional law of Member States, International law instruments of the universal character, as well as from the intellectual heritage of the Council of Europe. The EU added value consists in the special accentuation of those peculiarities, which are necessary for the smooth functioning of the Union as an area of freedom, security and justice and the enforcement of other legal institutes of a supranational character (for instance the accentuation of mutual trust between the Member States that the rule of law principles will be fully recognised by each of them).

\section{Current EU legal instruments for the protection of the rule of law (the procedures de lege lata)}

European Union law counts on several instruments, which can be used for the enforcement of maintaining the rule of law principles from the side of every

16 Ibidem, p. 10

17 Ibidem, p. 14

Published by Palacký University Olomouc, Czech Republic, 2019.

ISSN (print): 1213-8770; ISSN (online): 2464-6601 
Member State. These instruments were created gradually during the whole process of European integration, reflecting the phases of its development and the certain shift in its priorities (from purely economic aspects to common values).

These instruments vary from each other by the character of its procedure (judicial, political or administrative), by the participating subjects [(EU institutions - the Court of Justice, the Council, the European Council, the European Parliament, the Commission) and Member States] and by the potencial sanctions (or other consequences of the ruling). They are:

a) The infrigement procedure (Art. 258 TFEU)

b) The political procedure (Art. $7 \mathrm{TEU}$ )

c) The new framework to strengthen the rule of law (the procedure under the Communication COM (2014) 158)

\subsection{The Infringement procedure and its limit}

The judicial procedure known as ,the action for a Member's State failure to fulfil its obligations" under Art. 258 (or the infringement procedure) belongs to the traditional challenges, existing from the very beginning of the European integration. ${ }^{18}$ Although the fact, that it was never intended to be an exclusive measure against the breaches of the rule of law principles, nevertheless the universal character of this norm (which serves principally ,to enforce the actual application of Union law by a Member State in breach") ${ }^{19}$ had enabled to prevent it in numerous cases the violations just in this field.

Several rulings against Hungary and Poland have confirmed, that this procedure can be considered as an effective instrument for the protection of the rule of law, as well (see below).

At the same time they have shown the substantive limits of this instrument just in the field of the protection of common European values, as ,infrigement procedure can be lauched by the European Commission only where these concerns constitute, at the same time, a breach of a specific provision of EU law “20. Unfortunatelly to prove the clear link between non-fulfilment of obligations of the Member State under the specific norm of EU law and the breach of the principles of the rule of law is not always possible, as such violations may have a purely national (not European) dimension. They may consist, for instance, in the disbalance in separation of powers and other breaches in the functioning of democratic institutions at national level, as well as in the threats for the inde-

18 For the detailed description of this procedure see: LENAERTS, Koen, MASELIS, Ignace, GUTMAN, Kathleen: EU Procedural Law, Oxford University Press, Oxford 2014, p.p. 158214

19 Ibid, p. 159

20 Communication, ibid, p. 5 
pendence of national courts, etc. These limits of Art. 258 TFEU can be illustrated in several examples.

For instance, the Constitutional reform in Hungary (came into force on 1.1.2012) had caused at the European level a lot of concers about the different aspects of the rule of law in this Member State, especially the fears about the maintenance of the fair conditions for political competition, plurality of the media, the independence of Central Bank, the independence of a National supervisor on data protection, independence of judiciary ${ }^{21}$. To prove the existence of a clear linkage between this wide range of threats for the rule of law principles caused by the reform and the EU norms succedded only in 2 cases.

Especially, the Commission had managed to find out the sufficient legal basis at the level of the EU law for the triggering of the infringement procedure as concerning the independence of National supervision authority for the protection of personal data (C-288/12) and the compulsory retirement of judges, prosecutors and notaries (C-286/12).

For instance in the case C-288/12 22 the Court of Justice declared, that „by prematurely bringing to end the term served by the supervisory authority for the protection of personal data, Hungary has failed to fulfil its obligations under Directive 95/45/EC of the European Parliament and the Council of 24 October 1995 on the protection of individuals with regard to the processing of personal data and the free movement of such data“.23

In the case C-286/12 the Commission had to be much more inventive, as it was not possible to launch the procedure of Art. 258 TFEU due to the fact, that the matter was dealing with the issues of threat for independence of the Hungarian judiciarity, so it had a national dimension, regulated by the Hungarian Constitutional law. Therefore, the Commission „wisely chose the area of social policy/equal treatment in employment, where the EU competence is established and the Commission is entitled to start proceedings for failure to fulfil obligations under Directive 2000/78/ES“ ${ }^{24}$

21 For details see BUDÓ, Glória. EU Common Values at Stake: Is Article 7 TEU An Affective Protection mechanism? Documents CIDOB, 01, May 2014, p. 3 (online). Available at: https://www.cidob.org/en/publications/publication_series/documents_cidob_new_era/ eu_common_values_at_stake_is_article_7_teu_an_effective_protection_mechanism, accessed on 19.1.2018, p. 3

22 C-288/12 - Commission vs. Hungary, ECLI:EU:C:2014:237

23 ibid

24 RUFFER, Emil. The Commission's New Framework ort he Old Ingringement Under Article 258 TEU: Which are the Effective Means for Safeguarding the Rule of Law in the EU? In PÍTROVÁ, Lenka (ed.). Rule of Law and its Protection: Czech Perspective, Science and New Media. Passau-Berlin-Prague: 2015, p. 113 
Due to the fact that Hungary had fully complied with mentioned two Court's decisions and had partly modified its Constitutional reform in the related areas, the protection of the rule of law principles had been reached as well.

So, under certain circumstances the infringement procedure can serve as an sufficient legal instrument for the protection of the rule of law as well. But due to its essential limits (which were described above) this procedure will always create only a spare and subsidiary solution, something like as „a backdoor scenario“ concerning the protection of the common European values, which can be used in a frangmentary way and only in those cases, where the specific norm of EU law can be found.

\subsection{The political procedure under Art 7 TEU and its peculiarities}

On the contrary to this, the procedure under Art. 7 TEU was from the very beginning conceived as an exclusive instrument, created especially for the purposes of the protection of the rule of law principles. This norm, which was introduced by the Amsterodam Treaty in 1997, had reflected the certain fears of the "old" Member States about the maintance of the proper level of democracy in those states, whose accession was expected in the near future. So, this provision was primarely intended to be served as a certain safeguard for the maintance of the rule of law principles and other Copenhagen political criteria ${ }^{25}$ after the accession of the 10 countries of Eastern, Central and Southern Europe (accessed on 1.5.2004).

In this context, it is seemed to be as a certain paradox the fact, that the first serious discussions on the application of this article took place in connection with Austria, so one of the „old“ Member States (2000/Haider case, see below).

On the contrary to the previous legal instrument under Art. 258 TFEU, which creates the judicial procedure, in case of Art. 7 TFEU we are dealing with the purely political character of the procedure, which involves the political actors, and supposes the adoption of the decision taken by the political institutions of the EU (Council or European Council), which is made under the proposal of $1 / 3$ of Member States, or of the European Parliament, or from the Commission.

To the great "disadvantages" of this norm belong the extremely complicated and ponderous character of its procedures (preventive mechanism and sanctioning mechanism), as well as potential devastating impacts on the membership rights of the state concerned and on its citizens. The recent examples from practice have also showed, that in the case of the activation of this article, the eventual negative implications on the whole political climate in the European Union have not been excluded and even split among its Member States.

25 European Council in Copenhagen, 21-22 June 1993, Conclusions of the Presidency SN 180/1/93/ Rev 1. 
Due to the mentioned peculiarities of Art 7 TEU, it had „deserved“ a lot of titles and names, such as for instance the „nuclear option“ ${ }^{26}$ or the „last resort mechanism", etc. The extremely complicated character of the procedures under the Art. 7 TEU had even lead in jurisprudence to the birth of so-called „nuclear myths", the assumption that the, involving provision is extremely difficult and the results of its appplication are too devasting, to make this practicable “ ${ }^{27}$ The mentioned convinction about non-capability of this norm to be used in practice was also nourised by the fact, that during the long period of 20 years this political instrument had never been activated. However, at the time being the "nuclear myths" had already been "demolished“ and disproved by the triggering of the historically first political procedures, even in 2 cases (concerning Poland on the proposal of the European Commission in the December of 2017 and on the proposal of the European Parliament concerning Hungary in September 2018).

\section{Article 7 TEU and the proposals de lege ferenda}

Although the fact, that the essential changes in Article 7 were made by the Treaty of Nice and Lisbon Treaty (including the introduction of the preventive mechanism in the case of a, clear risk of the serious breach" of common European values), nevertheless a lot of unclear fomulations in the key notions of this provision necessarely demands the further changes in the wording of the mentioned article. Especially, it can be pointed out on the absolute lack of the definition or the description of the notion of the "serious breach of the values of Art. 2 TEU“ in the intention of the preventive procedure on the basis of para 1 Art. 7 TEU. The same refers to the determination of the content of the notion „existence of serious and persistent breach of common values" in the framework of the sanctioning mechanism (para 2 and para 3 of Art. 7 TEU).

Taking into account, that these notions are connected with finding out and the proving of the most relevant facts, which constitute the very core of the political procedure, the elaboration of the precisely defined criteria for determination of their content, creates no doubt a conditio sine qua non for the effective application of this provision in practice.

The previous experience, which had lead to the impossibility of activating this procedure due to the absence of the precise defined criteria just in the mentioned field (in Jörg Haider case, 2000), unambigiously confirms this conclusion.

26 This expression was used at first by the President of the Commission Jose Manuel Barroso in his speech „State of the Union Adress“ on 12 of September 2012, available at: http:// europe.eu/rapid/mess-release-SPEECH-12-596_en

27 The overview of these different approaches are given In KOCHENOV, Dimitry. Busting the Myths Nuclear: A Commentary on Article 7 TEU. EUI Working Papers, Law, 2017, no. 10, European University Institute, Department of Law, p. 6. (online). Available at: http://cadmus.eui.eu/bitstream/handle/1814/46345/LAW_2017_10.pdf? sequence=1\&isAllowed $=y$, accessed on 17. 4. 2018. 
But the most serious reservation refers to the essential vagueness and unclear determination of the scope of the sanctions, which can be imposed on the Member State in question. In other words, the formulation of para 3 of Art 7 TEU concerning that,$\ldots$ the Council, acting by a qualified majority, may decide to suspend certain of the rights deriving from the application of the Treaties to the Member State in question, including the voting rights of the representative of the government of that Member State in the Council", cannot be considered to be satisfactory as its gives too much space for different speculations and assumptions. This can be illustrated by an even brief glance at jurisprudence, when some of the authors are inclining to the restrictive interpretations, while other representatives of the doctrine are convinced, that this formulation involves both sanctions of economic and non-economic nature ${ }^{\text {" } 28}$. So, it is quite obvious, that the proper legal regulation must not leave any space for speculations and must be clear, unambiguous and legally predictable. Especially when it refers to the ruling, which is connected with so significant impacts on Member State and private parties. ${ }^{29}$

\section{The Procedure under the „A New EU Framework to strengthen the Rule of Law“}

This procedure, which was introduced by the Communication of the Commission from 11. 3. $2014^{30}$, is conceived as an additional mechanism to the already existing instruments (e.g. infringement procedure of Art. 258 TFEU and political procedure under Art. 7 TEU), and which is to be used in those cases, when the threats to the rule of law are of systematic nature. The anylysis of the content of this norm enables to conclude, that it creates de facto an administrative procedure, which consists of 3 stages (the Commission's assessment, the Commission's recommendation and follow-up of the Commission's recommendation).

The introduction of this additional procedure, which reflects the willingness of the Commission to initiate a further dialogue in order to find a solution with a Member State, is generally considered to be a very controversial. It is primarely due to the lack of the sufficient legal basis, as this norm was adopted in the form of the act of secondary law, without any legal grounds at the level of Founding Treaties.

28 KOCHENOV, Dimitry. Busting the Myths Nuclear: A Commentary on Article 7 TEU. EUI Working Papers, Law, 2017, no. 10, European University Institure, Department of Law, p. 8 (online). Available at: http://cadmus.eui.eu/bitstream/handle/1814/46345/LAW_2017_10. pdf? sequence=1\&isAlloed $=y$, accessed on 17.4.2018

29 ŠIŠKOVÁ, Naděžda. European Union's Legal Instruments to Strengthen the Rule of Law, their Actual Reflections and Future Prospects in: Šišková, N. (ed.): The European Union What is Next? A legal Analysis and the Political Visions on the Future of the Union, Wolters Kluwer Deutschland, Koln, 2018, p. 146

30 Communication from the Commission to the European Parliament and the Council „A new EU Framework to Strengthen the Rule of Law“, Strabourg, 11. 3. 2014, COM (2014) 158 final, p. 2 
In this connection the Legal Service of the Council in its very critical Opinion No 10296/14 had pointed out that: „Respect of the rule of law by the Member States cannot be, under the Treaties, the subject matter of an action by the intitutions of the Union irrespective of the existence of a specific material competence to frame this action, with the sole exception of the procedure described in Article 7 TEU. Only this legal basis provides for a Union competence to supervise the application of the rule of law, as a values of the Union, in a context that is not related to a specific material competence or that exceeds its scope" ${ }^{31}$

Following these grounds, the Council Legal Service declares in its opinion that „the new EU Framework for the Rule of Law as set out in the Commission's communication is not compatible with the principle of conferral which governs the competences of the institutions of the Union". ${ }^{32}$

So, it can be concluded, that although the fact, that this new mechanism was drawn as a certain alternative „between the political persuation and the „nuclear option“ of Art. 7 TEU “33, nevertheless, it is hardly acceptable, that just in the rule of law procedure the Commission acts without sufficient legal basis. That is why the relevant changes at the level of primary law (in the form of the widenning of Art. 7 TEU) are absolutely necessary. Another way, how to legitimize the current state (at least ad interim) is considered in the proposal of the Council Legal Service as follows: „the possibility exists for the Member States to agree among them on a review system of the functioning of the rule of law in the Member States and on the possible consequences to draw from that review. Such a review system as agreed by the Member States may foresee certain tasks to be carried out by the institutions of the Union". 34

The last comment towards the „New Framework“ is connected with the issues of the effectiveness of this procedure. In this respect it can be pointed out, that the historically first activation of this procedure towards Poland hadn't lead to the expected results, but vice versa it meant its total failure.

As the European Commission had stated in its Reasoned Proposal, that „after 2 years of dialogue and the adoption of 3 Recomendations the mentioned repeated efforts led to no results and did not prevented the further deterioration of the situation". 35

31 Council of the European Union. Opinion of the Legal Service 10296/14, Brussels, 27 May 2014, point 17 available at: http://data.consilium.europa.eu/doc/document/ST10296-2014-INIT/en/pdf

32 Ibid

33 This expression was used at first by the President of the Commission Jose Manuel Barroso in his speech „State of the Union Adress“ on 12 of September 2012, available at: http:// europe.eu/rapid/mess-release-SPEECH-12-596_en

34 Opinion of Legal Service, ibid, point 28

35 Reasoned Proposal in Accordance with Article 7 (1) of the Treaty of European Union Regarding the Rule of Law in Poland. Proposal for Council Decision on the determination of a clear risk of a serious breach by the Republic of Poland of the rule of law, COM (2017), 
This experience from practice must be undoubtely taken into account as well as properly reflected in the considerations about the future legal life of this mechanism and its prospects.

\section{Conclusions}

The brief overview made in this study and the analysis of different Union's legal instruments for the protection of the rule of law principles at the level of the EU enables to reach certain conclusions.

The EU law currently has at its disposal 3 different legal instruments, which can be used for the protection of common European values, including the rule of law.

These mechanisms differ greatly not only concerning the nature of the contained procedures (judical, political or administrative), but also in the relation to the effectivity of their application.

The infringement procedure, although the fact, that it creates an universal procedure which affects a great range of different kinds of non-fulfilment of the obligations from the side of the Member States, nevertheless its usage just in the mentioned field has a limited scope and coverage only in those cases, when the breach of the rule of law principles creates at the same time also the breach of the specific norm of the EU law (which is not always reachable).

The application of this procedure in order to affect a selected breaches of the whole pattern of non-compliance with the rule of law principles from the side of the Member State had been shown in many cases as satisfactory and sufficient. On the other hand it is not capable to prevent the breaches in the other fields and to avert the deterioration of the situation in general. That is why this mechanism can not serve as the main instrument for the intention of the protection of the rule of law principles and it will always remain a „backdoor" solution and a surrogate action in the sense of the protection of the rule of law.

Nothing will be changed by the considerations on the widenning of this article. For instance, the proposed solution by Guy Verhofstadt ${ }^{36}$ for expanding the grounds for the action of Art. 258 to include systematic infringement of EU values, is hardly acceptable due to its contradiction with the principle of the conferred powers, as the breach of the rule of law principles may have a purely national dimension.

From these aspects, the political procedure under Art. 7 TEU, which was "tailored“ exclusively for the protection of common European values, is much

835 final, Brussels, 20. 12. 2017/0360, p. 1-2

36 European Parliament (2016). Report on possible evolutions of and adjustments to the current institutional set-up of the European Union. (2014/2248(INI)). Available at: https://www. europarl.europa.eu/doceo/document/A-8-2016-0390_EN.html 
more capable of ensuaring the compliance of the rule of law principles from the side of Member States. Nevertheless, its effective usage demands sustantial changes and modifications in its text (on which it was pointed out in this study).

The third instruments in this field, the „new EU framework“, which was introduced by the Communication of the Commission, demands the creation of the appropriate legal basis as a conditio sine qua non for its proper legal status and the obtaining of the sufficient political authority.

The EU concept of the rule of law must be not only protected, but also further developed, including the elaboration of the precise criteria for its maintance and other structural elements of the rule of law, which are inherent to the Constitutional traditions of Member States (for instance the separation of powers, the independence of the media, etc.).

The significance of the observance of the rule of law principles will have even increasing tendency in the near future also due to the interference into the every day life of every person of modern technologies and the associated problems caused by this.

\section{References}

BUDÓ, Glória. EU Common Values at Stake: Is Article 7 TEU An Affective Protection mechanism? Documents CIDOB, 01, May 2014, p. 3 (online). Available at: https:// www.cidob.org/en/publications/publication_series/documents_cidob_new_era/eu_ common_values_at_stake_is_article_7_teu_an_effective_protection_mechanism, accessed on 19. 1.2018, p. 3.

DAMINOVA, Nasiya: The Charter of Fundamental Rights of the European Union as a factor affecting the „European consensus" notion (the example of due process rights) in: European Studies. The Review of European Law, Economics and Politics, 2017, vol. 4, p. $28-55$.

HAMULÁK, Ondrej: The Variations of Judicial Enforcement of the EU Charter of Fundamental Rights vis-á-vis Union Institutions and Bodies in: European Studies. The Review of European Law, Economics and Politics, 2018, vol. 5, p. 98-112.

KOCHENOV, Dimitry. Busting the Myths Nuclear: A Commentary on Article 7 TEU. EUI Working Papers, Law, 2017, no. 10, European University Institute, Department of Law, p. 6. (online). Available at: http://cadmus.eui.eu/bitstream/handle/1814/46345/ LAW_2017_10.pdf?sequence=1\&isAllowed=y, accessed on 17.4.2018.

LENAERTS, Koen, MASELIS, Ignace, GUTMAN, Kathleen. EU Procedural Law, Oxford University Press, Oxford 2014, p.p. 158-214

MULLER-GRAFF, Peter-Christian. The Idea and Rule of Law as Foundation of the EU Acquis in: Šišková Naděžda (ed.) From Eastern Partnership to the Association: A Legal and Political Analysis, Cambridge Scholars Publishing, Newcastle, 2014.

RUFFER, Emil. The Commission's New Framework or the Old Ingringement Under Article 258 TEU: Which are the Effective Means for Safeguarding the Rule of Law in the EU? In: PÍTROVÁ, Lenka (ed.). Rule of Law and its Protection: Czech Perspective, Science and New Media. Passau-Berlin-Prague: 2015, p. 113. 
SCHROEDER, Werner. The EU Founding values - Constitutional Character and Legal Impliations in: European Studies. The Review of European Law, Economics and Politics, 2016, vol. 3, p. 57.

ŠIŠKOVÁ, Naděžda, Dimenze ochrany lidských práv v Evropské unii, 2 edition, Linde, Prague, 2008, p. 91-92

ŠIŠKOVÁ, Naděžda. European Union's Legal Instruments to Strengthen the Rule of Law, their Actual Reflections and Future Prospects in: ŠIŠKOVÁ, Naděžda (ed.): The European Union - What is Next? A legal Analysis and the Political Visions on the Future of the Union, Wolters Kluwer Deutschland, Koln, 2018, p. 140

WEATHERILL, Stephen. Law and Values in the European Union, Oxford University Press, Oxford, 2016, p. 394

\section{Documents}

Communication from the Commission to the European Parliament and the Council „A new EU Framework to Strengthen the Rule of Law", Strabourg, 11. 3. 2014, COM (2014) 158 final, p. 2

C-294/83, Les Verts vs Parliament, ECLI:EU:EC:1986:166, para. 23

Opinion 2/13 of the Court, 18 December 2014, ECLI:EU:C:2014:2454

Communication from the Commission to the European Parliament and the Council „A New Framework to Strengthen the Rule of Law“, COM (2014) 158 final, Strasbourg: 12. 3.2014

Report on the Rule of Law adopted by the Venice Commission at its 86th plenary session (Venice, 25-26 March 2011, study no 512/2011, Strabourg 4 April 2011, CDL-AD (2011), $003 \mathrm{rev}$

C-288/12 - Commission vs. Hungary, ECLI:EU:C:2014:237

European Council in Copenhagen, 21-22 June 1993, Conclusions of the Presidency SN 180/1/93/ Rev 1.

President of the Commission Jose Manuel Barrosso. His speech „State of the Union Adress" on 12 of September 2012, available at: http://europe.eu/rapid/mess-releaseSPEECH-12-596_en

Council of the European Union. Opinion of the Legal Service 10296/14 point 17, Brussels, 27 May 2014 available at: http://data.consilium.europa.eu/doc/document/ST 102962014-INIT/en/pdf

Reasoned Proposal in Accordance with Article 7 (1) of the Treaty of European Union Regarding the Rule of Law in Poland. Proposal for Council Decision on the determination of a clear risk of a serious breach by the Republic of Poland of the rule of law, COM (2017), 835 final, Brussels, 20. 12. 2017/0360, p. 1-2

European Parliament (2016). Report on possible evolutions of and adjustment to the current institutional set-up of the European Union. (2014/2248(INI)). Available at: https://www.europarl.europa.eu/doceo/document/A-8-2016-0390_EN.html 